\title{
Totobuang Music Function as a Means of Emphasizing Cultural Identity Ambon City Community
}

\author{
Ketrina Tiwery ${ }^{1}$, Tjetjep Rohendi Rohidi ${ }^{2}$, Totok Sumaryanto ${ }^{3}$, Wadiyo ${ }^{4}$ \\ \{tiweryketrina@gmail.com ${ }^{1}$ \} \\ Graduate School, Universitas Negeri Semarang- Jawa Tengah, Indonesia
}

\begin{abstract}
Totobuang music is a traditional Ambonese music that is usually used in various events both religious and customary rituals, with a major diatonic scale without a semi-tone / half tone. Totobuang itself consists of small gongs, amounting to 12-16 pieces, and is usually combined with a drums that sound rhythm while totobuang produce melodies. This study aims to analyze and understand the function of totobuang music as a means of emphasizing the cultural identity of Ambon City people. The method used is a qualitative method with data collection techniques of observation, interviews and document studies, and triangulation techniques for analyzing data. The results showed that totobuang music function as a confirmation of the cultural identity of Ambon City people as accompaniment music, entertainment, means of communication, and cultural continuity. Totobuang music describes identity with the cultural values contained in it as a cultural characteristic of Ambon City people.
\end{abstract}

Keywords: Totobuang music, function, identity.

\section{Introduction}

Totobuang music is an ensemble that has been formed as a result of acculturation that was born and has its roots and has various functions in the lives of its owner community, namely the people of Ambon City. According to the results of the study put forward by Alfons, in the research description of the totobuang tifa music ensemble, totobuang is a musical instrument derived from Javanese gamelan, as evidenced by its name (percussion) and its physical form which is the same as bonang in Javanese gamelan. This instrument arrived in Maluku as a souvenir or souvenir between traders and people who have a position in the community [1].

At first totobuang entered the Maluku region in the form of gongs of different sizes. It is hung and beaten with a piece of wood. The gongs are an instrument that is highly valued in Ambon because it is a tool used in the adoption ceremony. Pela lift ceremony is a tradition of people in Maluku in tying ties of kinship between certain villages. At first totobuang was used as a souvenir or memento because of the relationship between Maluku and Java in terms of broadcasting Islam, which at that time numbered between 5-6 bonang, and in its development to date it has grown to 12 to 16 bonang [2].

In its development, totobuang music until now is often used in various rituals both religious and traditional in Ambon City. In addition, totobuang music is also used as entertainment music for the people of Ambon City. Another interesting phenomenon that occurs is totobuang music is often used as accompaniment music for bride and groom in 
procession from the blessing place / church / mosque to the reception area (bride house / special building). This became the inspirational rationale for studying totobuang's music function as a confirmation of the cultural identity of Ambon City people. How the people of Ambon City revive, inherit, and introduce totobuang music as one of the indigenous cultures of Ambon in a variety of traditional events as well as in national and international circles.

Based on this phenomenon, this study seeks to reveal how totobuang's music functions as a means of affirming the cultural identity of Ambon City people. Functions basically are interrelated systems between the constituent elements. The word function always shows the influence on something else [3]. The function of music concerns the purpose and consequences of the use of music (efficacy) in meeting social needs. Music is used in certain situations and is part of society, also has a deeper function [4].

The function of music in the development of a society reflects the cultural identity of the community. Artistic identity as an element of culture, is actually a unique symbol system that is used as a reference value by someone, which allows others to categorize it into a particular group. The manifestation of artistic identity is evident because of its manifestations in the form of works of art [5].

Thus this study aims to analyze and understand the totobuang music function as a means of asserting the cultural identity of Ambon City people.

\section{Research Method}

The method used in this study is a qualitative method that aims to describe and analyze the phenomena, events, social activities, attitudes, beliefs, perceptions, and human thoughts individually or in groups [6]. This research was conducted in Ambon City, with data collection techniques carried out through observation, interviews and document studies. Observations were made to observe and see directly the behavior patterns of Ambon City people. The interview technique used in this study is structured and unstructured with the aim to reveal or explore information in depth about totobuang music functions in Ambon City society. The purpose of the interview is to reveal or explore the projections of the informants' thoughts about the possible culture they have in the future [7]. Through document study techniques, data is obtained about images / photos, video recordings of totobuang music in the community.

The technique of checking the validity of the data is based on credibility criteria using the triangulation technique. While data analysis techniques are analyzed through the process of reducing, presenting and verifying data.

\section{Result and Discussion}

\subsection{Research Results}

Totobuang Music Function. Based on the purpose of the study, which is to analyze and understand totobuang music functions as a confirmation of identity, totobuang music functions are as accompaniment music, entertainment, means of communication, and cultural continuity. 
In accordance with the functions mentioned above, based on the results of interviews with several art actors, they claimed that totobuang music now had a place in the hearts of Ambon City people. Every event and event carried out always presents totobuang music as accompaniment music and entertainment, as a means of communication, and also as a medium of cultural continuity that exists in Ambon City society.

The results of interviews with totobuang music artists in several studios in Ambon City (JS, YS, IP) stated that all this time they usually received calls to fill the event at various activities in Ambon City, such as accompanying the procession procession, enlivening the anniversary. Ambon City and Maluku Province (usually at this event totobuang music performances are carried out in the middle of the city and some even use cars for processions around the City), filling out religious events both in churches and mosques (in this section, totobuang music is usually collaborated with hadrat music originating from the land of Batumerah which is predominantly Muslim), and performing national and international shows to introduce totobuang music to the outside community.

Totobuang Music Function As a Means of Confirming the Community Cultural Identity of Ambon City. According to interviews with several totobuang (RM, VJ, OR) artists, totobuang music does have similarities to gamelan music and usually totobuang musical instruments are ordered from Java, but have distinctive features and differences from Javanese gamelang music. Totobuang music has different scales from Javanese gamelang music, totobuang music uses a major diatonic tone ladder with a semi-tone / half tone while Javanese gamelang music uses pentatonic scales. The distinctive features of totobuang music can distinguish it from other traditional music in Indonesia. The distinctive features of totobuang music are used as identity and identity by the people of Ambon City as regional identity.

\subsection{Discussion}

Music Function totobuang. Based on the results of the above research, totobuang's music function is (1) as accompaniment music, totobuang music is always used as a accompaniment to the bridal procession and is also used to accompany dances (tari lenso) on the reception of the grand guests. The procession was carried out to comply with the rules and habits of the local community [8]. As a performance music, Sumardjo says that dance and music are means for communication with the realm of spirits and deities, and invite them to attend parties [9]. In wedding ceremonies, totobuang music represents a happy mood and is a cause of disarray because of the joyful atmosphere, and supported by the cheerful tifa. (2) Entertainment facilities, in the performance of totobuang music is often presented as a means of entertainment for the people of Ambon City at various events in Ambon City. The habit of the people of Ambon City in listening to totobuang music has become commonplace, the total melody with the rhythm of rhythmic tifa makes it hard for people to feel happy because it is used as a media of expression and recreation in eliminating fatigue and fatigue in their daily activities. The function of music as entertainment is that music is able to create feelings of joy and give a feeling of pleasure to the listener. Music has a pleasing function, making satisfaction with rhythm, language, melody, or regularity of musical harmony [4]. (3) Communication means, music has a communication function means that a music that applies in a cultural area contains its own signals that are only known by the people supporting the culture, this can be seen from the text or melody of the song / music [9]. Totobuang's musical melody itself has cultural values that reflect the identity of Ambon City people. Ambon city itself is a city that has experienced prolonged religious conflict, and totobuang music is one of 
the traditional music that communicates peace through collaboration totobuang and hadrat (based on the results of interviews with studio leaders Hatukau Batumerah, that at the time of the conflict and during periods of reconciliation), the mayor of Ambon at that time combined totobuang music from Christians / Christians and hadrat from the Salam / Islam to collaborate in displaying totobuang hadrat music in church buildings and mosques). This shows that totobuang music has a very large communication function for the people of Ambon City. (4) cultural continuity, in this function totobuang music is music that contains the teachings and norms in continuing the cultural system in the next generation. Totobuang music until now has been propagating in schools in Ambon City, both at the elementary, middle and high school levels. Totobuang music regeneration takes place in Ambon City society, so totobuang music can compete with other modern music.

Totobuang Music Function As A Means Of Confirming Ambon City Community Identity. Music can be used as the identity of an area where music is growing and developing. Totobuang music is the traditional music of Ambon City people who have distinctive characteristics and regional cultural values. The function of totobuang music in society illustrates the survival of totobuang music in a modern society, the acculturation of totobuang music makes people increasingly love totobuang music. Traditional music of an area symbolizes the identity of the area based on beliefs, language, and patterns of behavior [10]. States that the factors that shape cultural identity are belief, language, and behavior [11]. Ambon City people have characteristics, so they can shape their own culture. Totobuang music is present in the Ambon City community which has a very strong pela gandong bond (relationship between Islam and Christianity in Maluku), totobuang music is used as a symbol of community identity because it is a characteristic music of Ambon City society. The existence of art in this case music becomes a city icon or identity with a symbol attached to it as a sign of historical or contemporary work [12].

\section{Concultion}

The function of totobuang music in Ambon City society as accompaniment music, entertainment facilities, means of communication, and cultural continuity. Totobuang music becomes the identity of Ambon City community through cultural symbols that are in the form of cultural elements inherent in people's lives. Based on several functions found in totobuang music, it becomes a differentiator like an identity inherent in every society. Referring to the functions that exist in totobuang music, it is only natural that totobuang music is used as the cultural identity of Ambon City people. 


\section{References}

[1] M. rence Alfons, "Deskripsi Ansambel Musik Tifa Totobuang," Institut Seni Indonesia Yogyakarta, 1997.

[2] C. et al Gieben, Muziek en dans spelletjes en kinderliedjtes van de molukken. Hoevelaken: cps pg OOM, 1984.

[3] C. A. . Peursen, Strategi Kebudayaan. Yogyakarta: Kanisius, 1988.

[4] Al. P. Merriam, The Anthropology of Music. Chicago;North: Western University Press, 1964.

[5] T. . Rohidi, Kesenian dalam Pendekatan Kebudayaan, I. Bandung: ACCENT Graphic Communication, 2000.

[6] M. Djunaidi dan Fauzan Almanshur, Metodologi Penenlitian Kualitatif. Jakarta: Ar-Ruzz Media, 2012.

[7] S. Endaswara, Metode Penelitian Kebudayaan. Yogyakarta: Gajah Mada University Press, 2003.

[8] O. Septiana, T. Sumaryanto, and A. Cahyono, "Nilai Budaya Pertunjukan Musik Terbangan Pada Masyarakat Semende," Cathar. J. Arts Educ., vol. 5, no. 2, pp. 142-149, 2016.

[9] Wiflihani, "Fungsi Seni Musik dalam Kehidupan Manusia," Antrhropos J. Antropol. Sos. dan Budaya, vol. 2, no. 1, pp. 101-107, 2016.

[10] T. Su. F. Harriska, "Senggayung Music in Gerai Village, Ketapang Regency: The Study of The Form and Cultural Identity," Catharsis, vol. 7, no. 1, pp. 34-42, 2018.

[11] Alo Liliwari, Dasar-Dasar Komunikasi antar Budaya. Yogyakarta: Pustaka Belajar, 2013.

[12] A. H. Alvi Lufiani, Setiawan Sabana, "The use of value clarification technique-based- picture story media as an alternative media to value education in primary school," Harmon. J. Arts Res. Educ., vol. 17, no. 1, pp. 41-47, 2017. 